\title{
Pesquisa com Histórias de Vida na Produção da História da Educação em Ciências: o Dispositivo Fotobiográfico como Recurso para a Compreensão de Experiências Sociais
}

\section{Research with Life Stories in the Production of the History of Science Education: the Photobiographical Device as a Resource for the Understanding of Social Experiences}

\author{
Rodrigo Cerqueira do Nascimento Borba Brasil \\ Sandra Escovedo Selles Brasil
}

$\mathrm{O}$ acionamento de fontes históricas e de abordagens metodológicas diversificadas têm sido requisitadas para que novos conhecimentos sócio-históricos possam ser construídos em torno das constituições históricas das disciplinas Ciências e Biologia, possibilitando a compreensão de nuances, controvérsias e disputas. Deste modo, o presente texto almeja apresentar e problematizar a utilização de um recurso investigativo desenvolvido no campo das Ciências Sociais e ainda incomum nos estudos sobre Educação em Ciências em perspectiva histórica: a fotobiografia. Conjugando referenciais da Sociologia, da História do Educação e do Currículo e partindo de uma pesquisa sobre a trajetória social de uma professora de Ciências cujas práticas pedagógicas estiveram em intensa sintonia com os pressupostos do "Movimento de Renovação do Ensino de Ciências" das décadas de 1960 e 1970, é exercitado o uso do dispositivo fotobiográfico para acionar memórias e a produção de outros sentidos que sobre o que seria lecionar Ciências naquela conjuntura.

Palavras-chave: Educação em Ciências; fotobiografia; currículo.

The activation of diversified historical sources and methodological approaches have been requested to the production of a new socio-historical knowledge concerning the historical constitutions of the school subjects of science and biology. This approach allows the understanding of controversies and disputes about these subjects. The present paper aims to present and problematize the use of an investigative resource developed in the field of Social sciences and still unusual in the science education studies with historical perspectives: the photobiography. This device combines references from Sociology, History of Education and Curriculum. In the paper, the photobiography dialogues with a research on the social trajectory of a science teacher whose professional practices were in tune with the assumptions of the "Science Education Innovation Movement" of the 1960s and 1970. The photobiography device is used for triggering memories and the production of other meanings of science teaching at that milieu.

Keywords: Science Education; photobiography; curriculum. 


\section{Introdução}

Esse texto integra uma pesquisa mais ampla que se insere nos estudos do campo do currículo, em especial da história das disciplinas escolares Ciências e Biologia e focaliza a trajetória de uma professora atuante no magistério secundário da rede pública municipal do Rio de Janeiro na segunda metade do século XX. Para tal, lança mão de referenciais teórico-metodológicos do campo da Sociologia para problematizar elementos desta trajetória em diálogo com a História da Educação e o Currículo. Em especial, nosso foco recai sobre a pertinência de explorar estudos biográficos, mobilizando esses referenciais, de modo a contribuir para o entendimento da história das disciplinas escolares supramencionadas.

O interesse pela docente se deve ao fato de que esta pautou sua prática profissional de forma alinhada ao "Movimento de Renovação do Ensino de Ciências" cuja importância se encontra em registros da literatura como Abrantes e Azevedo (2010), Azevedo (2020), Cassab (2015), Fracalanza, Amorosino e Gouvea (1987), Gomes (2008), Gomes, Selles e Lopes (2013), Krasilchik (2000) e Marandino, Selles e Ferreira (2009). Tal Movimento teve seu fortalecimento entre as décadas de 1960 e 1980, voltando-se às disciplinas escolares de caráter científico, apostando na produção de materiais didáticos, no ensino experimental e nas metodologias inspiradas nas práticas científicas. Isto porque o "Movimento de Renovação de Ensino de Ciências" se articulava a finalidades educacionais que visavam o incremento da produção científico-tecnológica do país e fomentavam a elaboração de outros padrões para o ensino de Ciências e para a formação de professores na área (Ayres, \& Selles, 2012; Azevedo, Selles, \& Lima-Tavares, 2012; Fracalanza, 2009; Krasilchik, 2000).

No âmbito deste "Movimento de Renovação", a professora cuja trajetória elegemos contar protagonizou práticas pedagógicas e enunciou discursos que a projetaram enquanto uma professora inesquecível e notável ${ }^{1}$ (Lopes, 2013, 2016). Trata-se de Nilza Bragança Pinheiro Vieira, professora que lecionou Ciências de 1963 até 1995 na Escola Municipal Camilo Castelo Branco (EMCCB), localizada no bairro do Jardim Botânico, Zona Sul carioca. De acordo com os indícios já reunidos em torno de sua trajetória social ${ }^{2}$ (Dubar, 1998) nosso interesse se justifica pelos seguintes motivos: Nilza destacou-se na condição de participante do Centro de Ciências da Guanabara (CECIGUA) nas décadas de 1960 e 1970; como autora de livros didáticos de Ciências na década de 1970; foi

1 As pesquisas de Lopes $(2013,2016)$ sobre profissão docente em perspectiva histórica indicam processos de identificação do corpo docente de instituições educacionais que notabilizam determinados professores e os tornam inesquecíveis. O prestígio decorre de seu apelo à "vocação" como explicação para sua escolha profissional, nível de formação docente, do modo como se deu o acesso à carreira, ao valor social de suas disciplinas escolares, a sua articulação com redes de sociabilidade e instâncias onde circulavam, além da repercussão e do alcance de materiais didáticos produzidos.

2 De acordo com Dubar (1998), as análises das trajetórias dos sujeitos sociais devem articular aspectos múltiplos do processo biográfico para que seja possível compreender suas construções identitárias. Isso significa dialogar as práticas e posições sociais objetivas com as marcas das subjetividades nas narrativas produzidas em entrevistas de histórias de vida. 
formadora de uma comunidade professores em projetos curriculares na década 1980 e uma das pioneiras na realização de atividades de Educação Ambiental no Rio de Janeiro, conforme indicam Scarton e Selles (2012).

O estudo se apoia também no reconhecimento de que existe uma demanda por estudos sócio-históricos sobre a disciplina escolar Ciências que não somente questionem sua constituição, seus laços com as ciências de referência e com outras formas de conhecimento disseminadas socialmente (Santos, \& Selles, 2014), mas também que sejam especialmente dirigidos para a compreensão de trajetórias docentes de maneira articulada às transformações na sociedade (Ayres, \& Selles, 2012). Deste modo, nos servimos do dispositivo da fotobiografia para nos aproximarmos das concepções que notabilizaram a atuação de Nilza Vieira.

Elegemos explorar a trajetória dessa professora para entender ideias que conferiram destaque à sua prática pedagógica, e suas conexões com a história da disciplina escolar Ciências. Para isso, empregamos a fotobiografia, pois se trata de uma metodologia de trabalho biográfico que, mesclando narrativa e imagem, oportuniza um exercício reflexivo tanto para o entrevistado - que produzirá sentidos ao tecer e interligar suas recordações -, quanto para o entrevistador que buscará apreender e interpretá-los em conjunto com seu entrevistado (Bruno, 2014). Ademais, em sintonia com Bourdieu e Bourdieu (2006) vislumbramos as fotografias como objetos propícios para leituras sociológicas a partir da análise dos usos sociais, dos sentidos atribuídos a esse tipo de registro e das próprias práticas fotográficas, que não devem ser vistas reduzidas a si mesmas em termos técnicos ou estéticos.

Por isso, este texto encontra-se organizado de modo que, a seguir, será apresentada uma breve problematização sobre as potências e limitações do trabalho biográfico. Depois, apresentaremos o dispositivo fotobiográfico construído junto com Nilza Vieira e a partir dele tecemos algumas reflexões sobre sua narrativa, bem como mobilizaremos ressalvas metodológicas. Ao final, pontuaremos algumas considerações à guisa de conclusão. Com esse texto, buscamos fazer um exercício que pode contribuir para as pesquisas em História da Educação em Ciências no Brasil, tendo em vista que o campo da História do Currículo e das Disciplinas Escolares tem sido hibridizado e tensionado por diferentes perspectivas teórico-metodológicas, como apontam Cassab (2010) e Fonseca, Xavier, Vilela e Ferreira (2013).

\section{O trabalho com dispositivos fotobiográficos}

$\mathrm{O}$ artigo se situa teórica e metodologicamente na perspectiva dos estudos biográficos e o recorte da pesquisa aqui apresentado aciona uma narrativa autobiográfica de Nilza Vieira. Tal narrativa foi produzida em um depoimento que seguiu os procedimentos qualitativos recomendados para os trabalhos com História Oral (Delgado, 2011) e com narrativas sobre histórias de vida de professores (Goodson, 2015). A entrevista foi realizada na residência da professora, gravada em áudio e durou quase quatro horas. Sob o formato semi-estruturado, a entrevista almejou apreender a 
trajetória da professora nos seguintes aspectos: origens sociais; percursos formativos inicial e continuado; ingresso na docência e estabelecimento profissional; inserção em redes de sociabilidade e solidariedade; produções curriculares.

Compreendendo que o trabalho com trajetórias de professores demanda o cruzamento de diferentes fontes históricas (Goodson, 2015; Lozano, 1996), neste trabalho, optamos por exercitar o uso de fotobiografias. O dispositivo fotobiográfico é construído a partir de uma seleção de registros imagéticos provenientes de um acervo biográfico. Dentre as fotografias que disponibiliza para o investigador, o depoente a ser biografado seleciona aquelas que estejam relacionadas a sua história de vida e escolhe as mais significativas a seu ver. Em seguida, o entrevistado é convidado a contar uma história que integre as imagens selecionadas, tendo como arcabouço integrador elementos de sua trajetória pessoal e profissional para assim produzir uma narrativa autobiográfica (Bruno, 2014). Desta forma, vale lembrar a percepção de Delory-Momberger (2012) quando defende que a produção de estudos biográficos são convites para que o outro se revele ao representar e reapresentar o passado, uma vez que o devir biográfico não é algo dado, o que impossibilita que conheçamos os sujeitos sociais antes de ouvi-los nesse tipo de pesquisa. O pesquisador também participa do processo de construção da biografia, pois ela é fruto da interação dialógica construída no momento de produção da entrevista, da transcrição da oralidade e da interpretação pela ótica do investigador, que cruza a narrativa a outras fontes (Goodson, 2015; Portelli, 1997).

Em nossa pesquisa, seguimos as orientações resumidamente mencionadas acima e de modo mais detalhado apresentadas por Bruno (2014) para instarmos Nilza Vieira a revisitar sua atuação como professora de Ciências a partir de fotografias tiradas na década de 1970, guardadas em seu acervo biográfico pessoal. Era nosso propósito instigar uma narrativa que contemplasse seu olhar para a Educação em Ciências, bem como abarcasse sua experiência docente, algumas práticas pedagógicas desenvolvidas e suas principais concepções sobre o que seria aprender e ensinar. No entanto, também consideramos que a captura dos momentos que compuseram a fotobiografia apresentada, a preservação das fotografias e a seleção de imagens operada pela professora não foram feitas de forma neutra. Entender que os registros aqui discutidos podem não ter sido produzidos de forma acidental ou para serem efêmeros (Bourdieu, \& Bourdieu, 2006) é uma precaução metodológica que diminui o risco de monumentalização ${ }^{3}$ (Le Goff, 1996) das ações de Nilza Vieira ou de empreendermos uma análise acrítica de suas memórias.

Em seu texto sobre a ilusão biográfica Bourdieu (1996) tece críticas às abordagens subjetivistas que não consideram as condições objetivas que explicariam o curso das experiências subjetivas, contribuindo assim para uma concepção ilusória da realidade social. Porém, se por um lado, o gênero biográfico é alvo de críticas pelo risco de atribuições de racionalidades às histórias de vidas - que podem constituir narrativas que não raro se apoiam em coerências e linearidades que jamais existiram efetivamente

\footnotetext{
3 De acordo com Le Goff (1996), as memórias são construções seletivas. Assim, nem tudo é registrado pelos sujeitos sociais ou é enunciado quando lembrado. Por variarem em função da forma como são articuladas, estruturadas e expressas, as memórias devem ser um ponto de constante atenção para o pesquisador.
} 
-, concordamos com Sabina Loriga (1998) sobre a importância dos estudos biográficos para a produção de uma história das experiências, do cotidiano e das minorias. Dentre as diferentes tipologias biográficas elencadas por Levi (1996), avaliamos que a modalidade narrativa de biografia e contexto é a que mais se aproxima de nossa proposta de trabalho. Nesse caso, as especificidades da biografia são preservadas, "todavia a época, o meio e a ambiência também são muito valorizados como fatores capazes de caracterizar uma atmosfera que explicaria a singularidade das trajetórias" (Levi, 1996, p. 175).

Ademais, a utilização desse dispositivo metodológico para a mobilização do capital narrativo ${ }^{4}$ (Goodson, 2007) em torno das práticas curriculares estabelecidas por Nilza Vieira se encontra em anuência às prerrogativas que Daniel Bertaux (2009, 2014) confere ao trabalho biográfico. Para Bertaux $(2009,2014)$, os mundos sociais não permitem que as narrativas autobiográficas produzidas pelos sujeitos sejam vistas de forma isolada, uma vez que eles constroem suas histórias a partir do que é herdado e vivido nos cenários em que estão inseridos. Em outras palavras, os sujeitos não estão descolados do tempo e do espaço social: o capital narrativo é mobilizado tomando por base sua experiência, seu julgamento e os sentidos que construiu ao longo deles.

Para esse autor, ao construir memórias, provocar narrativas e cotejar os cursos de ação dos indivíduos o pesquisador deve desenvolver uma escuta narrativa que possibilite a observação e a compreensão do jogo social a partir do outro. Tal movimento permite que sejam reconhecidas e desveladas redes de posições/relações sociais, culturais e econômicas. Além disso, Bertaux $(2009,2014)$ argumenta em prol do abandono da ideia de que pesquisas qualitativas, tal qual a biográfica, são falhas apenas por serem ancoradas fortemente nas subjetividades, enquanto a objetividade da pesquisa quantitativa per se a tornaria mais verossímil e verdadeira. Coadunamos com essa crítica à percepção objetivista que vê as narrativas sempre como ilusórias. Por isso, empreendemos o exercício apresentado a seguir.

\section{Escrevendo histórias e inscrevendo experiências com a fotobiografia}

As falas apresentadas neste texto foram extraídas de uma entrevista realizada pelo primeiro autor na residência de Nilza Vieira no início de 2019. A entrevistada assinou o assentimento e a cessão de direitos sobre o depoimento oral e autorizou sua identificação nominal quando do uso das informações prestadas. Ademais, também foi consentida a utilização das fotografias de seu acervo pessoal para a pesquisa em foco e sua publicação nos materiais de divulgação da mesma, tais como artigos e trabalhos completos.

Nilza Vieira ingressou em 1956, com 19 anos de idade, no curso de História Natural da Universidade do Brasil (UB) - atual Universidade Federal do Rio de Janeiro -, onde se graduou em 1960. No ano seguinte, realizou um curso de especialização em Genética e Evolução sob orientação de Antônio Geraldo Lagden Cavalcanti na UB, que

4 Goodson (2007) elabora e opera com esse conceito inspirado na obra de Pierre Bourdieu. O capital narrativo é aquele relacionado à capacidade de alguém pensar e teorizar sobre suas próprias narrativas de história de vida, produzindo sentidos para as experiências e negociando significados para projetos futuros. 
contou com um período de estágio junto a Oswaldo Frota-Pessoa na Universidade de São Paulo. Casada com o físico Cândido Oromar Figueiredo Vieira ${ }^{5}$, professor da UB e docente atuante no Centro de Ciências da Guanabara (CECIGUA), Nilza foi aluna, professora e coordenadora de cursos oferecidos no CECIGUA ao longo das décadas de 1960 e 1970. Sua atuação no magistério público municipal do Rio de Janeiro perdurou de 1963 até 1997. Durante a maior parte desse tempo, a professora dedicou-se a atuar como regente, ministrando a disciplina escolar Ciências na EMCCB, no bairro do Jardim Botânico. Nas décadas de 1970 e 1980, a docente atuou na formação de professores, recebendo estagiários de cursos de Ciências Biológicas. Eles participavam sob sua supervisão de atividades pedagógicas variadas e alguns foram seus alunos no $1^{\circ}$ grau. Dentre as produções curriculares de Nilza, estão um livro didático e seu respectivo guia metodológico para subsidiar o trabalho dos professores (Vieira, Vieira, \& Silva, 1970, 1972).

No acervo de fotografias que retratavam suas atividades enquanto professora de Ciências constavam 41 imagens distintas. Dentre estas, para compor a presente fotobiografia, a docente selecionou 13, todas relacionadas a aulas em campo que ela tinha o costume de ministrar na Praia da Urca, Rio de Janeiro. Tal seleção foi realizada a pedido do entrevistador, que solicitou à depoente que escolhesse dentre as fotografias apresentadas aquelas que pudessem ajudá-la a contar uma história sobre suas práticas docentes. $\mathrm{O}$ pesquisador não opinou sobre quais registros deveriam ou não compor o recorte. Não foi possível saber se todas as fotografias foram feitas na mesma ocasião ou se são registros de diferentes encontros. No entanto, no verso de uma das imagens ela havia assinalado o ano de 1971, possível ano de realização da atividade revisitada aqui e que coincide com as lembranças trazidas durante seu depoimento.

Vale mencionar que muitas vezes as fotografias são produzidas para eternizar e solenizar atividades ou práticas pouco rotineiras, com a intencionalidade de se fabricar uma determinada representação de si mesmo ou de um grupo social no qual o sujeito que fotografa ou é fotografado se insere. Assim, é interessante enxergar as imagens abaixo como fontes que permitem o registro visual de relações e papéis sociais que se quisera conservar (Bourdieu, \& Bourdieu, 2006).

Convém ressaltar que as atividades em campo são uma das fortes tradições curriculares dentro do Ensino de Ciências e Biologia, herança da História Natural (Marandino et al, 2009). Nesse bojo, nos defrontamos com as reflexões de Claude Dubar (1998), que entende que as trajetórias sociais devem ser problematizadas a partir da relação indivíduo-sociedade e analisadas de forma associada aos processos de objetivação e subjetivação que se referem, respectivamente, às posições sociais objetivas ocupadas durante a vida e aos elementos subjetivos que podem ser expressos nos relatos biográficos. Por isso, observar que Nilza Vieira se graduou em 1960 no curso de História Natural da Universidade do Brasil talvez nos dê pistas de o porquê as aulas em campo seriam tão valorizadas em sua prática profissional a ponto dos registros de atividades na

5 Falecido em abril de 1971. 
Praia da Urca serem elencados para a produção do dispositivo fotobiográfico em questão. Essa seleção também nos indica que a Praia da Urca se tornou e pode ser assumido como um lugar de memória ${ }^{6}$ (Nora, 1993) presente na narrativa da professora.

Interessantemente, sua narrativa fotobiográfica começa com a lembrança de um experiente professor de Ciências que ela admirava, pai de um amigo de seu marido. A partir da lembrança das histórias contadas por esse senhor, denominado por ela como Doutor Moisés, e trazendo à tona o sentimento de reconhecimento positivo por aqueles que gostam de ensinar, Nilza Vieira inicia a sua narrativa. Ao longo desta seção, apresentaremos as fotografias de acordo com a ordem que ela sinalizou durante a produção do depoimento, entremeando as transcrições com as imagens e com algumas ponderações. Todas as falas apresentadas neste artigo são oriundas de uma entrevista com Nilza Bragança Pinheiro Vieira concedida ao primeiro autor em 03 de janeiro de 2019 na sua residência. A professora inicia seu depoimento assumindo a terceira pessoa do singular. Este modo de se narrar pode ser entendido como a intenção de compartilhar com o entrevistador o lugar de observador, provavelmente para se expressar mais livremente acerca de si e marcar seu autojulgamento sobre as cenas fixadas pela fotografia:

Era uma vez uma moça deslumbrada pelo ensino e ela conheceu um rapaz também deslumbrado pelo ensino. Ela da Biologia e ele da Física. Ele tinha um amigo, que virou um amigo em comum, e era pai de um amigo dele que também era professor de Ciências. Então o que fascinava o rapaz - que era o Cândido - nesse senhor era ele saber ensinar. E os casos que ele contava: mil casos sobre a sala de aula, como que ele ensinou isso e aquilo. E aí ele [Cândido] levou, como que para mostrar um tesouro, levou a moça, que era a Nilza, para conhecer o Doutor Moisés e ela também ficou fascinada. Passávamos noites ouvindo-o contar os casos dele da sala de aula e ao mesmo tempo ela foi construindo a sua prática pedagógica pelo o que ele dizia.

Diante deste depoimento inicial, em que Nilza mobiliza tantas memórias que justificariam parte de seu fascínio pela docência, é válido reafirmar as histórias de vida como fontes fecundas para pesquisas sobre a profissão e a formação docente. Isto porque permitem que sejam apreendidas dimensões das trajetórias de professores que auxiliam a compreensão de suas práticas pedagógicas e de seus espaços de socialização (Lelis, 2014). Aqui, podemos ver o quanto para Nilza Vieira foi importante ter outro professor, mais experiente, como modelo profissional a lhe inspirar.

Ademais, por trabalharmos com a subjetividade e a memória nessa narrativa sobre a história de vida da docente, temos a oportunidade de ultrapassar representações essencialistas sobre o que foi ser professora para ela, ao passo que o desafio torna-se pensar como sua história de vida se comunica com outras histórias, com as experiências vividas e com os contextos que as forjaram (Lelis, \& Nascimento, 2010). Prosseguindo

6 Segundo Nora (1993), os lugares de memória são espaços materiais, simbólicos e funcionais caracterizados por uma aura ritualizada e não espontânea que transforma memória em história. Os lugares de memória, além de preservarem e atribuírem sentidos à memória coletiva, ainda corroboram para a invenção ou o reforço de identidades. 
na elaboração da fotobiografia, emergiu um relato que expressava uma sensação de realização profissional no momento em que Doutor Moisés, o professor que ela tanto admirava, foi prestigiar uma de suas aulas de campo na Praia da Urca (Figura 1):

E a maior glória dela foi que anos depois ele foi um observador da prática dela. Mais do que um observador, ele foi lá. Mais idoso ainda, 10 anos mais idoso, para aprender o que os aluninhos dela estavam ensinando sobre o mar. Ele se debruçou para olhar na bacia o que eles estavam mostrando e ensinando. E na cabeça dela passou um filme vendo o que ele devia estar pensando: ela chegava lá, universitária deslumbrada pela história dele e agora ele está vivendo a história dela [grifo nosso].

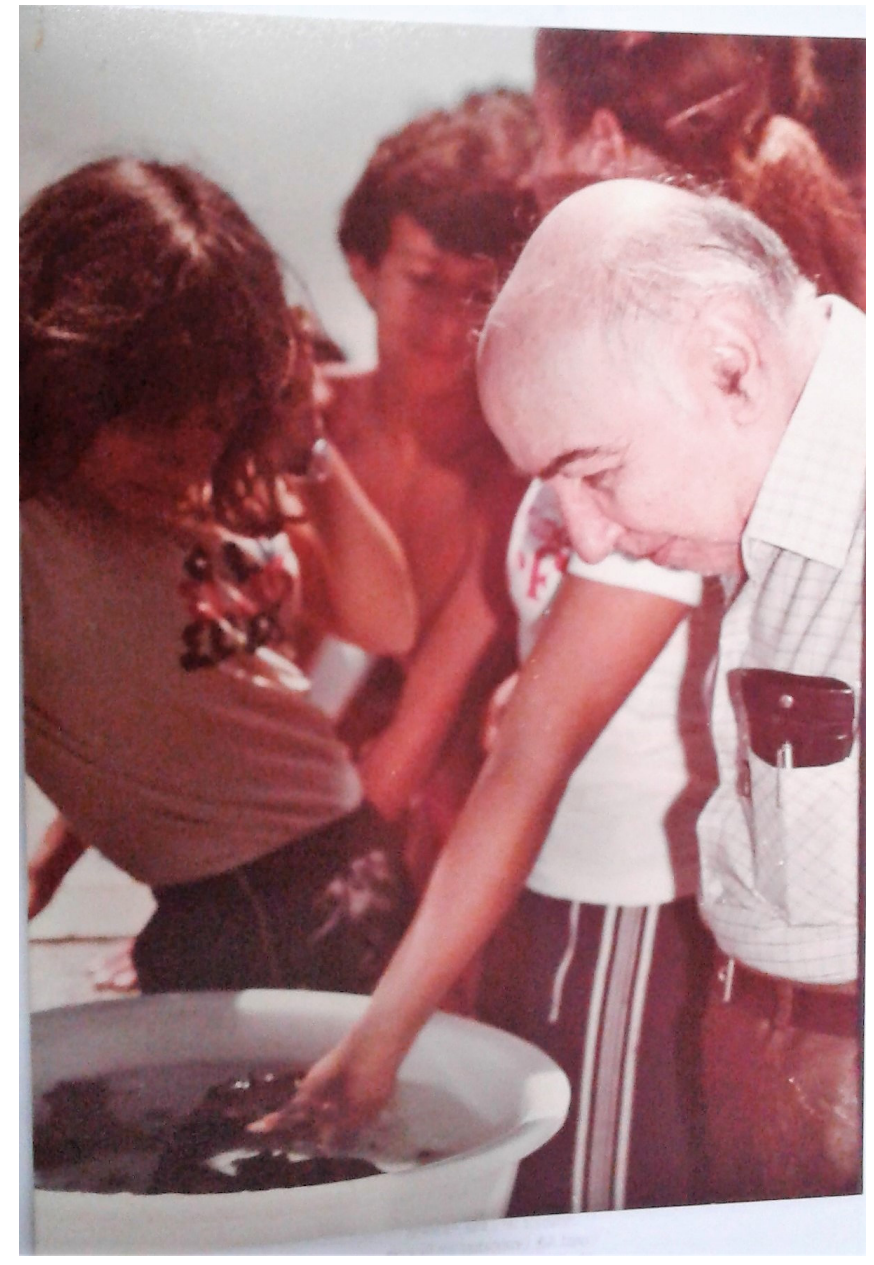

Figura 1. Doutor Moisés, profissional admirado por Nilza Vieira, visita sua aula de campo

Fonte: Acervo fotográfico pessoal de Nilza Vieira

Diante da Figura 1 e das considerações iniciais da professora, podemos vislumbrar o acionamento deste registro de Doutor Moisés tal qual um troféu que conota a importância social da prática pedagógica desenvolvida por Nilza Vieira. Esse é um dos usos das fotografias assinalado por Bourdieu e Bourdieu (2006) que despertam nossa atenção: o acionamento de registros e a elaboração de discursos que possam servir 
ao enaltecimento de quem é representado nas fotos. Tal qual sugerem os autores, Nilza escolhe narrar-se "de fora", utilizando a terceira pessoa do singular.

Por sua vez, Goodson (2007) argumenta em prol da relevância de se mobilizar aspectos das histórias de vida e das trajetórias profissionais de professores ao se estudar a História das Disciplinas Escolares, pois assim é possível estabelecer mais facilmente interligações entre os sujeitos e as estruturas sociais. Tal autor também nos desafia a "ver o indivíduo em relação à história de seu tempo, permitindo-nos encarar a interseção da história de vida com a história da sociedade, esclarecendo assim escolhas, contingências e opções com que se depara o indivíduo" (Goodson, 1992, p. 75). Assim, talvez compreendamos porque Nilza Vieira, mulher, viúva de um físico e professor universitário, mãe e professora secundária, tenha evidenciado tanto orgulho ao se narrar na terceira pessoa do singular. Confundindo-se com a personagem que ela mesma criou para a fotobiografia, ao contar sobre o trabalho pedagógico que desenvolveu explica o sucesso que fazia quando parava seu carro na Praia da Urca com os materiais para a aula de campo (Figura 2):

E uma das partes da história dela é de um orgulho enorme. Ela tinha um carro grande, claro, nunca tive um carro zero, mas era um carrão. O carrão parava na beira da calçada, perto da murada na Urca e aí de dentro do carro saía um monte de coisa.

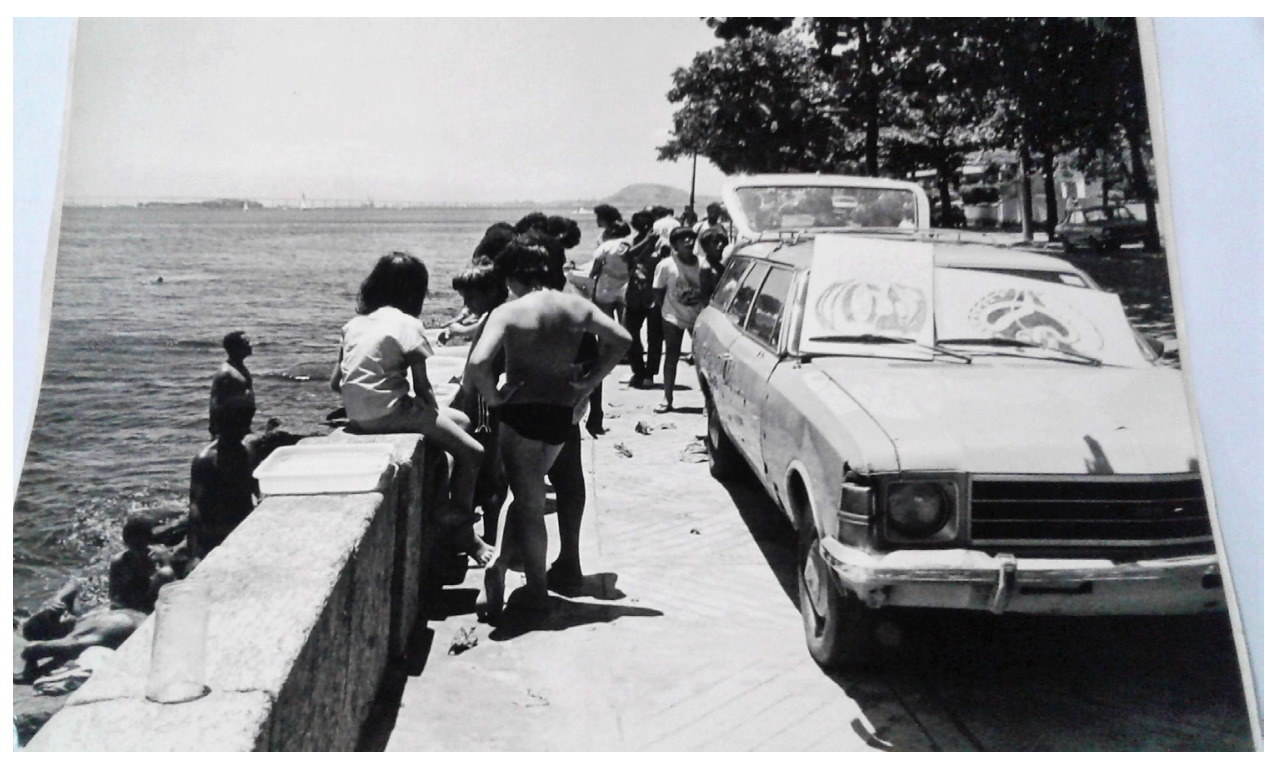

Figura 2. Estudantes e estagiários na mureta da Praia da Urca ao redor do carro de Nilza Vieira Fonte: Acervo fotográfico pessoal de Nilza Vieira

É importante evitar um olhar ingênuo para as memórias, sejam elas individuais ou coletivas, tendo em vista que sempre são seletivas (Le Goff, 1996). Logo, atentemos para o fato de que na narrativa de Nilza Vieira é apresentado um tipo de dinâmica de aula de campo difícil de se concretizar em um ambiente aberto e externo ao espaço escolar atual, com risco de acidentes, com pessoas estranhas circulando ao redor dos 
estudantes e que necessitaria de recursos materiais e logísticos para coleta e manutenção de animais aquáticos marinhos como indicam as Figuras 3, 4, 7, 8, 10, 11 e 12. Afinal, disputas, constrangimentos e hesitações muitas vezes não são trazidas à tona por quem rememora ou por quem deseja enquadrar memórias ${ }^{7}$ (Pollak, 1989, 1992), como pode ter acontecido para a produção dessa fotobiografia, tendo em vista a ênfase dada aos movimentos livres dos estudantes e à ausência de adultos os monitorando. Também não pode ser ignorado que, por mais que pareçam espontâneas, a fotografias são registros fabricados para apresentar deliberadamente posturas que exaltem sentimentos e valores específicos de acordo com os propósitos dos sujeitos envolvidos com o retrato (Bourdieu, \& Bourdieu, 2006). É prudente, portanto, não olvidarmos isso ao prosseguirmos na leitura das imagens e da transcrição:

O espantoso é que quem vinha no carro eram só crianças e jovens, ela era a única adulta. E aí as coisas eram espalhadas, mas havia ordem. Ninguém tomava conta de ninguém, cada um tomava conta de si e ajudava o outro. Rapidamente se separavam, cada um sabia o que fazer.

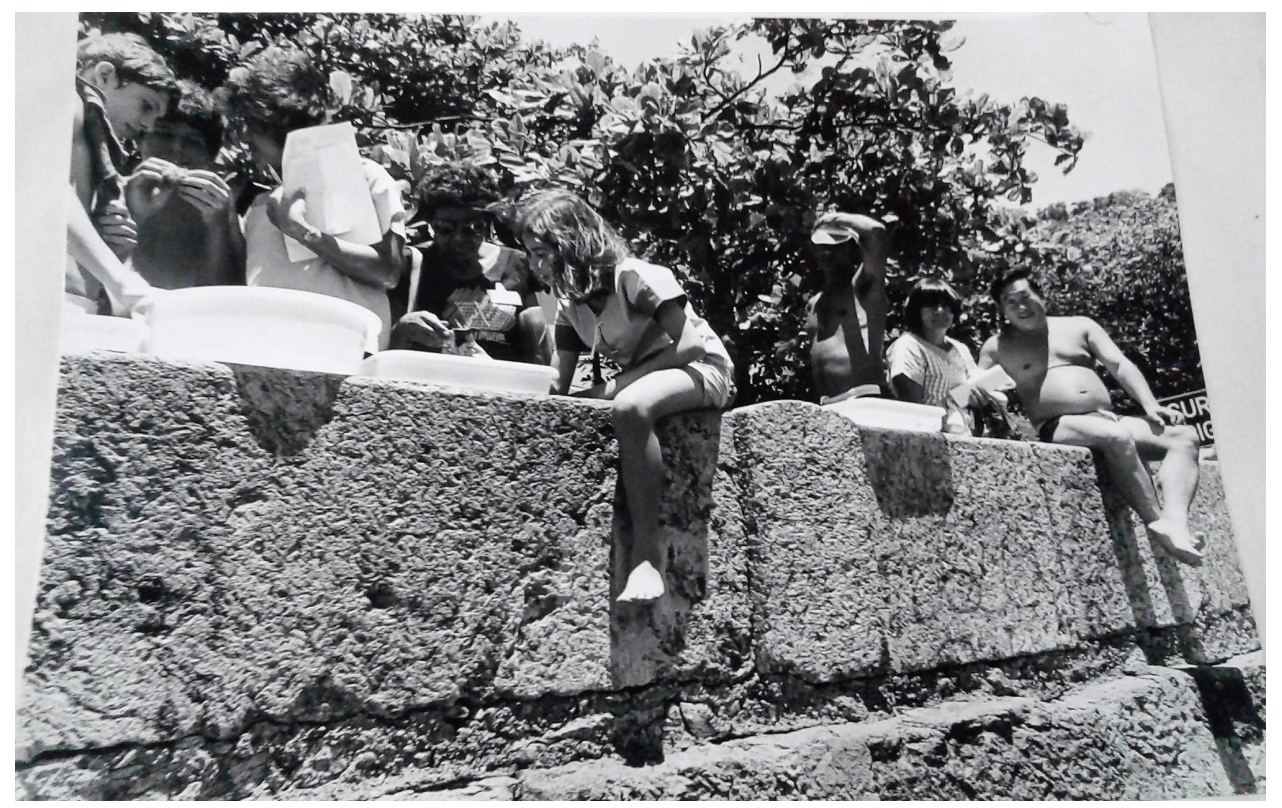

Figura 3. Alunos de Nilza Vieira e o que parecem ser transeuntes observando bacias com animais marinhos na mureta da Urca

Fonte: Acervo fotográfico pessoal de Nilza Vieira.

A narrativa de Nilza enfatiza sua postura como professora zelosa, organizada e próxima dos estudantes. Seu discurso retrata um trabalho pedagógico ritualizado,

\footnotetext{
7 Michael Pollak $(1989,1992)$ aciona a categoria de memória enquadrada para se referir à memória coletiva que é construída a partir de operações que selecionam e consolidam determinadas lembranças e versões do passado, mesmo de dentro de limites e seguindo certos critérios. Desta forma, o enquadramento de memórias é um recurso para manter a integridade do tecido social e o funcionamento das instituições. Porém algumas memórias são relegadas a silêncios ou esquecimentos até que possam vir à tona em momentos de graves crises.
} 
cercado por uma aura quase mágica a respeito da aula em campo ministrada. A seleção de fotografias e as falas que correspondem à leitura e à interpretação de cada uma delas pela depoente também são fatores que servem às ritualizações. As imagens são objetos de trocas reguladas, retratando eventos intensos da vida social e reafirmando a unidade de grupos (Bourdieu, \& Bourdieu, 2006), algo também explícito na história contada por Nilza Vieira. Porém, em seguida, a professora realizou uma ressalva sobre o modo como o coletivo estudantil era regulado, tendo em vista o cuidado com a vida e o bem estar de seus alunos em um ambiente de campo, algo condizente com uma postura docente responsável.

Como nem todas as crianças que estavam sob sua supervisão sabiam nadar, exalunos de Nilza que realizam cursos de graduação em Ciências Biológicas também eram convidados para participar das aulas em campo, auxiliando na coleta e na devolução de animais marinhos aos seus habitat:

Quem sabia mergulhar ia mergulhar, mas quem não sabia não se atrevia, porque, se desse errado, a professora é que ia pagar o pato. E aí todos iam ser proibidos de continuar fazendo, então só mesmo quem sabia mergulhar é que se atrevia.

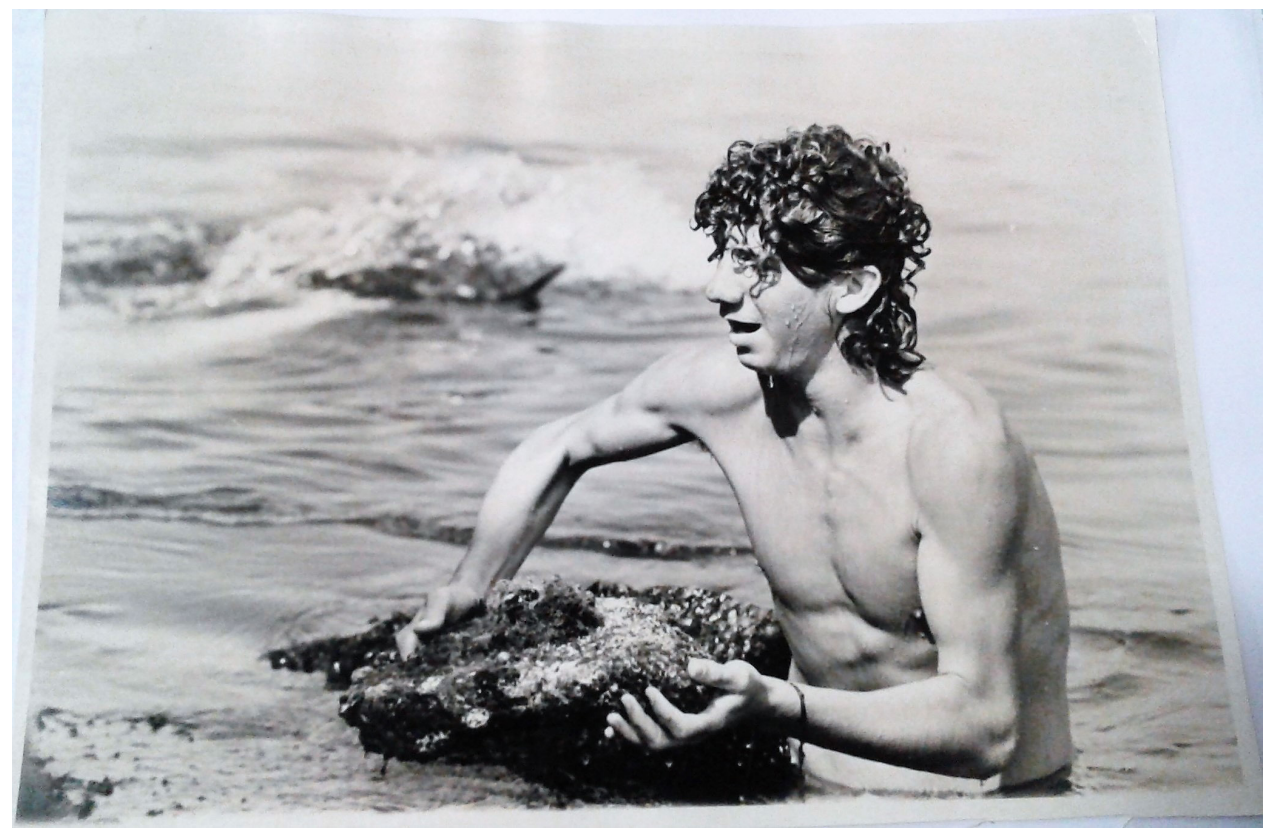

Figura 4. Ex-aluno da EMCCB, então estudante de graduação em Biologia, atuando como auxiliar voluntário na aula de campo coletando animais marinhos na Praia da Urca

Fonte: Acervo fotográfico pessoal de Nilza Vieira

A Figura 4 de modo especial convoca nossos olhares para a impressão claramente transmitida por um ex-aluno de Nilza Vieira na EMCCB que emerge do mar carregando amostras de material biológico. $\mathrm{O}$ sujeito fotografado e o próprio ângulo da fotografia sugerem a intenção de transmitir a ideia de que aquele era um instante solene a ser reverenciado. Ao mesmo tempo, essa deferência na postura assumida pelo rapaz ao ser 
fotografado carrega um sinal de tentativa de controle da objetificação de sua própria figura operada pelo retrato fotográfico (Bourdieu, \& Bourdieu, 2006). A seleção dessa fotografia para compor a história narrada também pode ter sido realizada com o intuito de enfatizar que havia adultos que mergulhavam no mar durante a aula de campo para realizar o trabalho mais perigoso.

Esse cuidado trazido em sua fala e explicitado pela imagem pode nos remeter à sua responsabilidade com a integridade física das crianças e ao julgamento de seus pares. Afinal, ela ia contra a cultura escolar hegemônica e as práticas pedagógicas que valorizam aulas expositivas. Além disso, sabemos que as disciplinas escolares são organizadas a partir de disputas e negociações travadas nas comunidades disciplinares ${ }^{8}$ (Goodson, 1997). Assim, os professores que defendiam o "Movimento de Renovação", alinhados à perspectiva de Nilza, tenderiam a aprovar sua abordagem didática, mas outros colegas, nas disputas internas na escola (ou entre escolas) poderiam responsabilizá-la e penalizála diante de qualquer problema.

Por isso, conforme salientam Santos e Selles (2014), é preciso entender os valores e interesses dos sujeitos envolvidos na elaboração e na circulação de ideias relacionadas ao currículo escolar. Isto favorece a compreensão das redes de sociabilidade e solidariedade de professores, permitindo que encontremos evidências sobre determinados discursos e as influências destes nas disputas em torno da disciplina Ciências. Nesse sentido, estavam discursos que valorizavam a experimentação, o trabalho com coleções didáticas e as saídas de campo, todos praticamente contemplados pela atividade proposta por Nilza Vieira e emblematicamente representados nas fotografias em que alunos estudam a anatomia de animais recém-coletados no costão rochoso da Praia da Urca (Figuras 5 e 9). No entanto, o ar de informalidade, euforia e liberdade discente total retornou à narrativa tão logo a ressalva sobre as consequências de um eventual acidente foi feita:

E os outros? Os outros ficavam vibrando espalhados por ali. Um sol danado, todo mundo vibrando, uns com camisa, outros sem, sem ninguém tomando conta. Nunca havia problema. E aí o que vinha do mar quem trazia ia levar. Não importa que na escola fosse aquele dito mal elemento, reprovado não sei quantas vezes. Ali, ele soube mergulhar. Ele foi além da professora, ele era maior que a professora porque ele sabia mergulhar, sabia se mexer dentro d'água, descobrir os animais marinhos e trazer pra todo mundo. Crescia mais do que a professora.

O trecho anterior e a Figura 5 representam bem a importância que o desenvolvimento de postura protagonista por parte dos estudantes tinha para Nilza. O entusiasmo e a relativização de possíveis estereótipos atribuídos a seus alunos, expressos em sua narrativa, evidenciam uma dimensão subjetiva da construção de suas práticas como docente. Além disso, o registro fotográfico conduz para um contínuo reforço de uma representação crível dos indivíduos e das ações que integravam aquele grupo social,

8 Comunidades disciplinares são grupos sociais heterogêneos formados por professores, pesquisadores e demais profissionais que constituem e mobilizam as disciplinas. Tais grupos disputam recursos e poder, podendo se apropriar de determinados padrões curriculares (Goodson, 1997). 
oferecendo uma constante atualização dos processos cotidianos de reconhecimento mútuo (Bourdieu, \& Bourdieu, 2006).

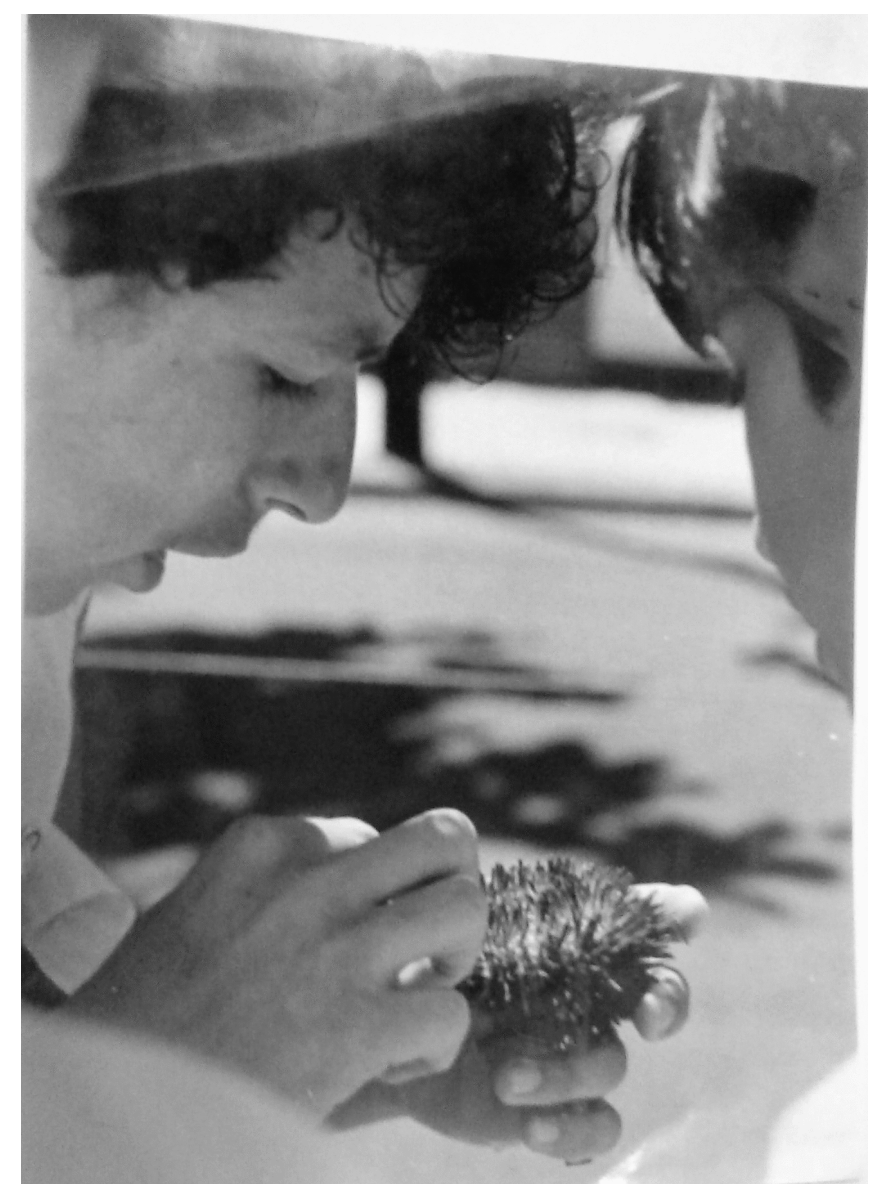

Figura 5. Alunos de Nilza Vieira observado um ouriço-do-mar em aula de campo na Praia da Urca

Fonte: Acervo fotográfico pessoal de Nilza Vieira.

Assim, de acordo com o depoimento de Nilza Vieira, ela valorizaria práticas não autoritárias e de comunicação não violenta ao lidar com estudantes, estagiários e colegas, preferindo uma relação horizontalizada (Figura 6) à medida em que constituíase professora:

E aí a cumplicidade. Nós não precisávamos de nota 0 pra quem não se comportava e de nota 10 pra quem se comporta. Nós precisávamos de cumplicidade e ela ia sendo criada. Os laços iam sendo feitos todos. Sem ninguém tomando conta, sem ameaças, sem nada. 


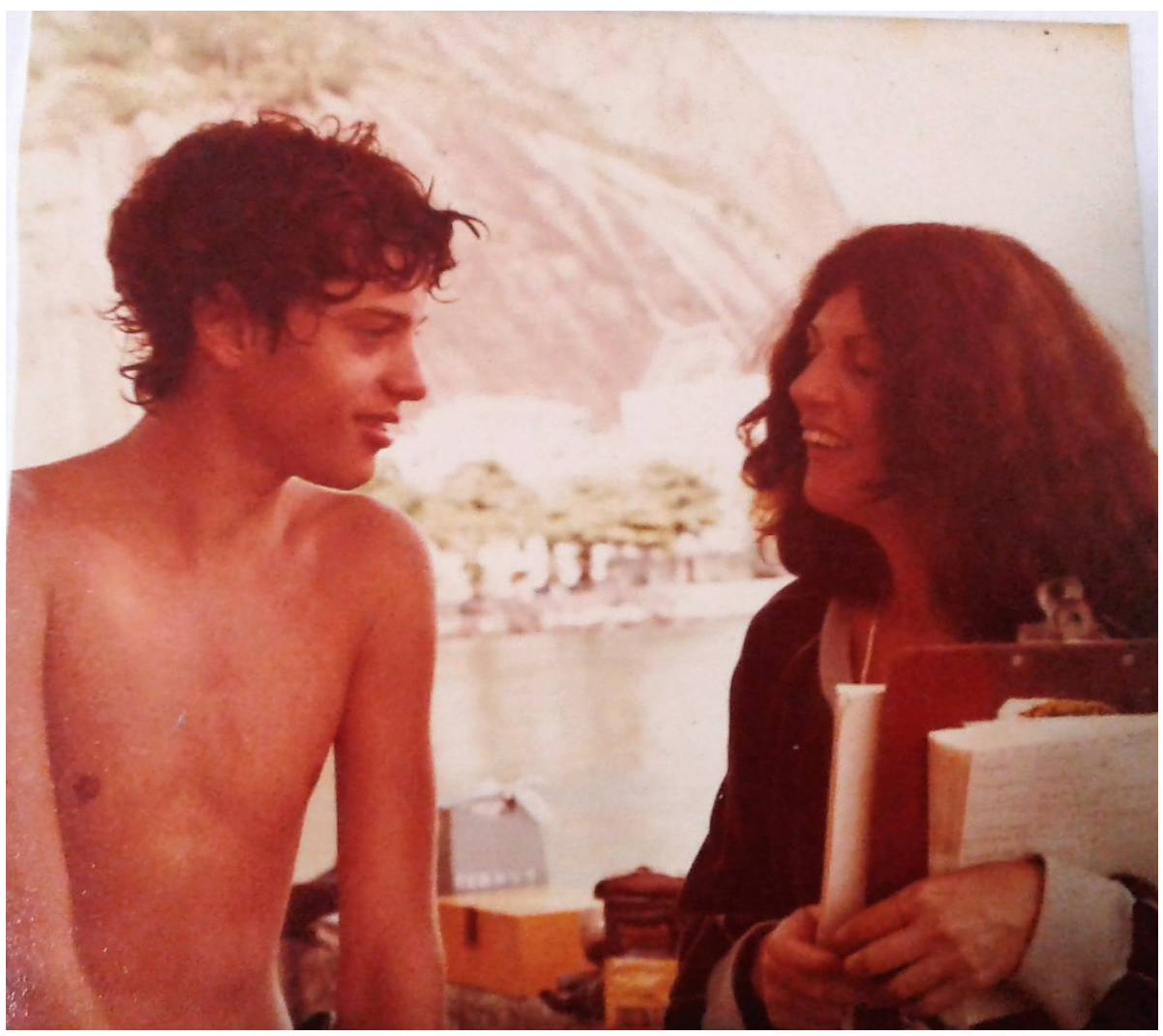

Figura 6. Nilza Vieira ao lado de aluno na Praia da Urca

Fonte: Acervo fotográfico pessoal de Nilza Vieira.

Por sinal, a escolha do que seria a captação da aludida horizontalidade parece querer testemunhar a imagem que Nilza Vieira pretende apresentar de si mesma. Fica claro, nesta e nas demais imagens em que a professora aparece interagindo com seus estudantes, que o que deve ser apreendido pelo leitor da fotografia não é propriamente as figuras da professora e do aluno, mas sim os papéis e as relações sociais construídas naquele contexto (Bourdieu, \& Bourdieu, 2006). A isto se acrescente a crítica que a professora faz ao sistema de avaliação escolar que atribui nota aos alunos - e não a seu desempenho -, confusão a que ela parece não querer aderir em sua proposta pedagógica, pelo menos nas saídas de campo registradas nas fotografias.

A notória ênfase na autonomia dos estudantes, que se desdobrava na possibilidade de um ensinar ao outro ou de se autogerirem sem uma constante intervenção da professora nesses processos, pode indicar uma questão central da sua constituição enquanto docente inscrita em uma complexa trama sócio-educacional. Este modo de orientar sua prática também remete ao "Movimento de Renovação de Ciências", ressignificando os centros de interesses e o protagonismo do aluno presentes no ensino ativo defendido pelo escolanovismo dos anos 1930, conforme sugerem Abrantes e Azevedo (2010). Para os autores, mais do que introduzir metodologias ativas, no "Movimento de Renovação do Ensino de Ciências" a agenda escolanovista é gradativamente ressignificada pela 
influência de sujeitos e de práticas científicas nas decisões curriculares que, entretanto, cumprem outra agenda e disputam poder com os educadores.

Além disso, naquele momento o Brasil atravessava um regime autoritário e a crítica ao arbítrio da avaliação nas disciplinas escolares pode significar um afastamento que a professora também gostaria de ressaltar. E, mais do que isso, pode nos ajudar a compreender as representações que a docente teria de si mesma e das relações que estabelecia com os demais atores escolares balizadas por sua experiência (DeloryMomberger, 2012), de certa forma se apresentando como uma professora que buscava elaborar e socializar outros padrões e tradições curriculares para a disciplina escolar Ciências:

E a cumplicidade onde na mesma história cada uma ocupava seu espaço sem ter quem dirigisse. Se dirigiam sozinhos, havia uma vontade comum, uma busca comum e ela acontecia. E aí o menininho que estava mergulhando, agora, era ele quem era o professor dos menores ou até às vezes dos maiores, do povo que se juntava para aprender. Os pais de família que passavam com os filhos, quem fosse, todos ali estavam ensinando.

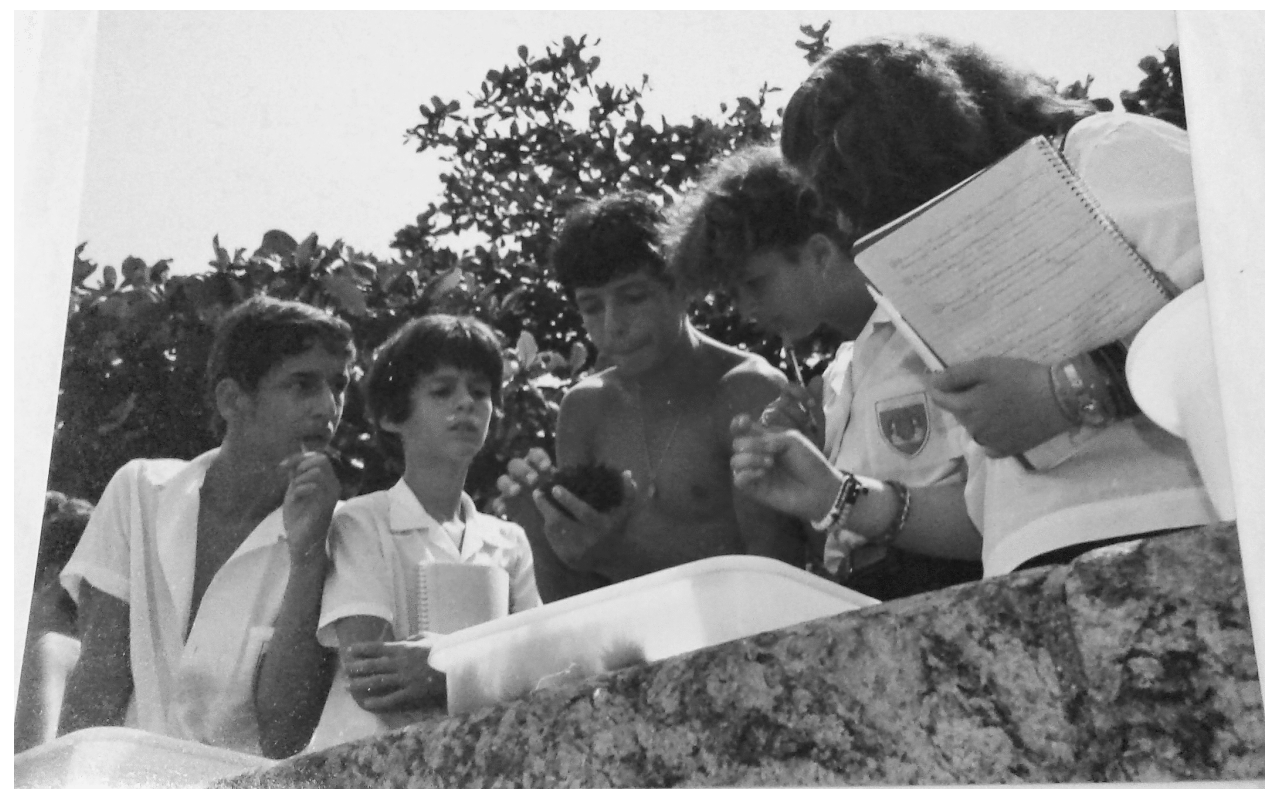

Figura 7. Alunos de Nilza Vieira observando animais marinhos na mureta da Urca auxiliado por um ex-aluno e pela professora

Fonte: Acervo fotográfico pessoal de Nilza Vieira.

Nesse momento da fotobiografia, cabe recuperar André Chervel (1990), autor que assinala o quanto as disciplinas escolares são construções singulares específicas da escola e nos indica que é valioso entender a dinâmica cultural do sistema escolar a partir do estudo delas. Ao colocar em evidência o caráter criativo da escola e defender certa autonomia das instituições educativas em relação à constituição de suas matrizes curriculares, o autor contribui para que compreendamos que as disciplinas escolares são também espaços de produção de saberes, reconhecendo processos de produção 
disciplinar que são inerentes às instituições escolares. Dessa forma, a narrativa de Nilza Vieira remete a essa perceptiva de Chervel quando cria formas de ensinar que se diferem de outras convencionalmente empregadas. A produção de saberes pelos atores escolares parecia ser tão eloquente que, segundo Nilza, provocava até estranhezas em quem se deparava com sua turma tendo aula naquele espaço:

E aí a surpresa: que escola é essa? Pensavam que era uma escola particular caríssima da Zona Sul [região nobre do Rio de Janeiro] e era um orgulho enorme o nosso dizer: Escola Municipal Camilo Castelo Branco. É uma escola pública. Todos ensinavam. Quem aprendeu pode ensinar. Quem sabe ensina e os outros aprendem.

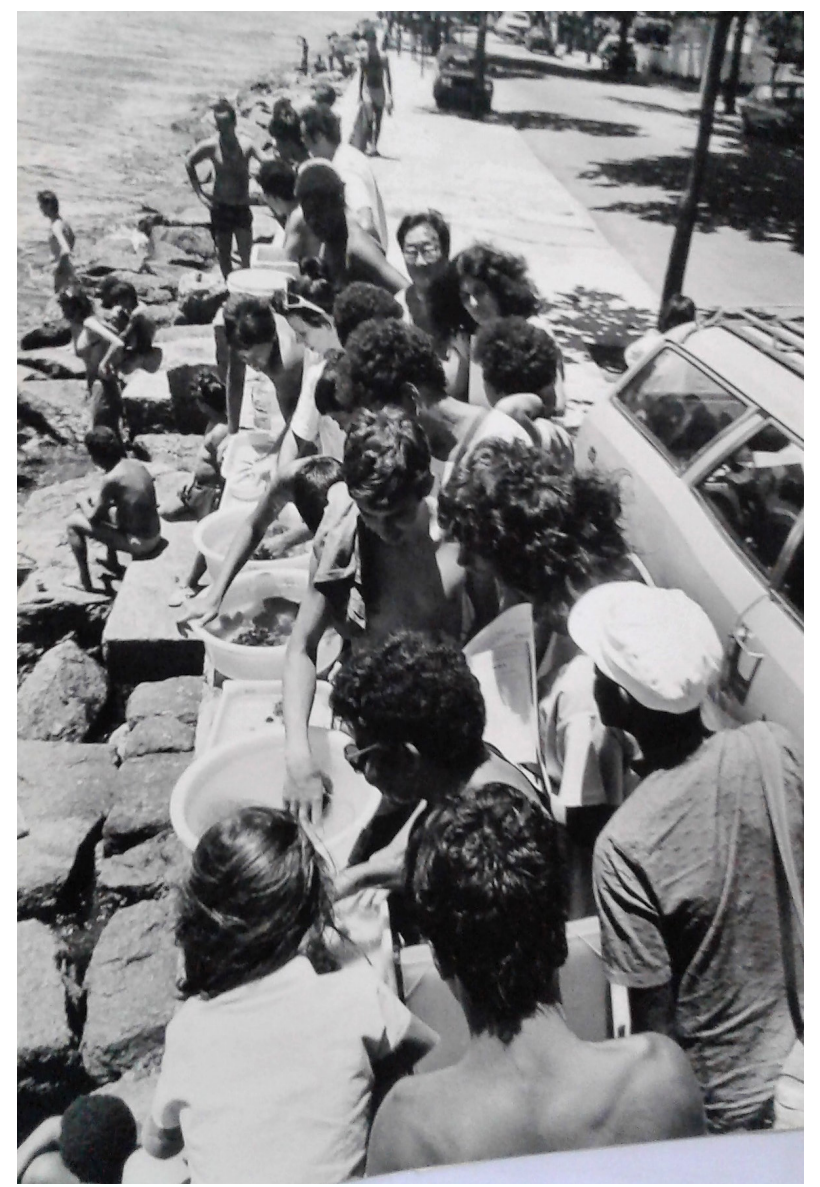

Figura 8. Alunos de Nilza Vieira e o que parecem ser alguns transeuntes observando a aula sobre animais marinhos na Praia da Urca

Fonte: Acervo fotográfico pessoal de Nilza Vieira.

Diante dessas práticas e representações que conferiam sentidos plurais ao modo como a disciplina escolar Ciências parecia estar sendo cotidianamente produzida por ela, havia também outras alusões claras às ideias do "Movimento de Renovação do Ensino de Ciências", tendo em vista que ocorria a valorização de perspectivas acadêmicas ao se trabalhar os conhecimentos escolares: o foco do trabalho recaia sobre conhecer biodiversidade da praia, entendendo as adaptações evolutivas dos seres vivos 
e categorizando-as de acordo com as classificações taxonômicas então vigentes. Além disso, ao evocar discursos socialmente prestigiados, o relato do orgulho de dizer o nome da escola pública, como rememora, pode ser um indício do que considera ter ajudado a obter reconhecimento social diante dos padrões forjados para o bom professor de Ciências da época, no quadro do ideário do Movimento de Renovação do Ensino de Ciências. Tal destaque remete ao "valor como moeda no mercado da identidade social", conforme afirma Goodson (1997, p. 27).

Mas, se os outros aprenderem, também poderão ensinar. Então havia uma multiplicação contínua: quem aprendia ensinava. Como todo mundo aprendia porque todo mundo sabia ensinar muito bem, então todos podiam ensinar. Não havia essa diferença entre professor e aluno.

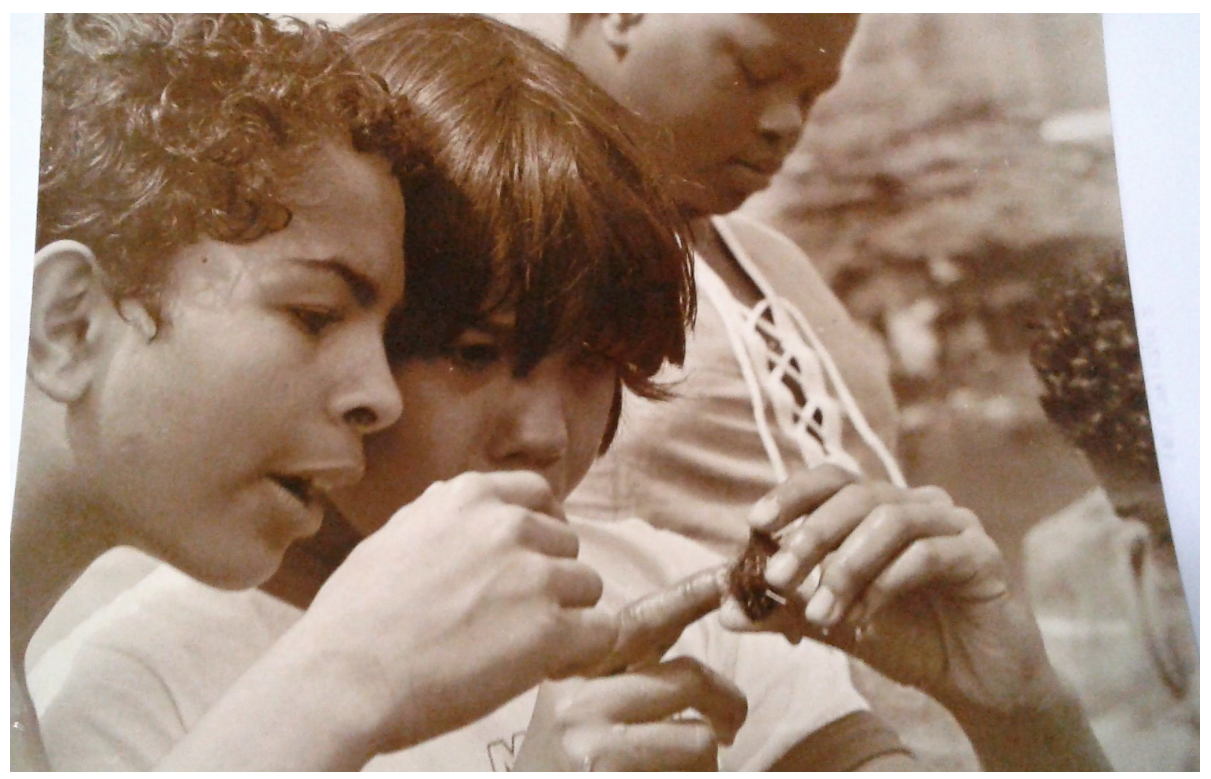

Figura 9. Alunos de Nilza Vieira manuseando um animal marinho em aula de campo

Fonte: Acervo fotográfico pessoal de Nilza Vieira.

Mais uma vez, diante do discurso que reforça que tudo transcorria muito bem e que todos eram capazes de ensinar uns aos outros sem distinções, é necessário atentar para o risco de monumentalização (Le Goff, 1996) da experiência de Nilza Vieira enquanto professora de Ciências na Escola Camilo Castelo Branco. Isso ocorre porque as memórias, tanto individuais, quanto coletivas, são fabricadas por recordações e lapsos, frutos de manipulações conscientes ou não. Assim sendo, as memórias, bem como os demais rastros e pistas deixados pelo/sobre/no passado, são produções dos sujeitos e de suas épocas no tempo presente, e no caso desta pesquisa, na apresentação das fotografias e de suas justificativas.

Nesse sentido, é possível indiciar que, pelo menos para os estudantes, não eram todos iguais frente ao binômio discente-docente. E isso era percebido pela própria professora, como fica claro no trecho seguinte. Nele, também há referência ao seu 
colega de graduação, de trabalho na EMCCB e compadre, Walter de Mello Veiga da Silva, também professor de Ciências e coautor do seu livro (Vieira et. al, 1970, 1972). Tais práticas se associam aos empreendimentos do "Movimento de Renovação", que buscava forjar novas tradições para o ensino de disciplinas científicas, mas também, como assinala Cassab (2015) visava garantir o prestígio social da ciência em meio aos processos de fortalecimento de instituições científicas no país e de modernização dos sistemas escolares:

Todos se juntavam e o orgulho maior é que eles [os estudantes] sempre achavam que eu sempre sabia mais. Nunca abusaram da minha autoridade, porque eles achavam que eu sempre tinha mais ainda a ensinar. Sempre eu a inventar mais e isso por gerações e gerações. Dez anos antes, o Walter estava lá na mesma posição com outros alunos, outras vestimentas. Os meus [alunos] mais livres, esses mais vestidos, fazendo a mesma coisa. E às vezes essas mesmas coisas valiam uma viagem a Paris de uma semana, de um prêmio pra um que foi dividido em três. ${ }^{9} \mathrm{E}$ como isso era contínuo, a história continuava.

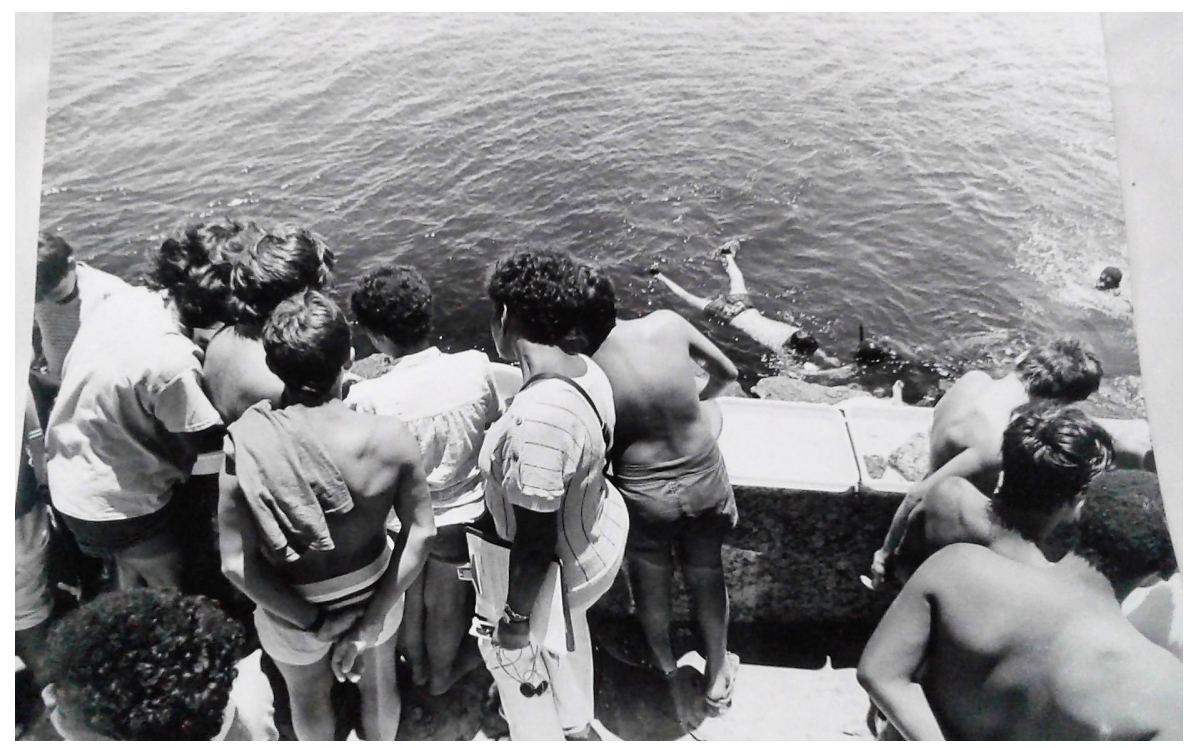

Figura 10. Alunos de Nilza Vieira, e o que parecem ser transeuntes, observando e coletando animais marinhos na Urca

Fonte: Acervo fotográfico pessoal de Nilza Vieira.

Neste trecho, apesar da horizontalidade na relação professora-alunos, fica evidente que a autoridade era dela. Isto parece estar baseado também no quanto a mesma tinha consciência do conhecimento que detinha e de que era capaz de construir junto com estudantes e estagiários. Assim, parece-nos que a horizontalidade se configurava mais

9 De acordo com informações prestadas em outro momento de seu depoimento, Nilza afirma que em 1971 seu colega de trabalho, Walter Veiga da Silva, inscreveu um projeto que desenvolveu voltado ao ensino de Ciências em uma competição que tinha como prêmio principal uma viagem à Paris. Ganhou o concurso e dividiu o prêmio entre três alunas que participaram do projeto. Nilza Vieira, de licença em decorrência do óbito de seu marido, não participou diretamente deste projeto. 
como um pressuposto para ensinar e sua crença nele é coerente com a intencionalidade didática de que fala Forquin (1992). Por outro lado, ao informar que seu colega na década anterior já realizava uma aula em campo de formato semelhante, tal depoimento pode conversar com sua suposição de que a abordagem pedagógica estaria estabilizada. Ao comentar o prêmio, ela parece querer legitimar esta abordagem.

Além disso, amparados nas reflexões de Bourdieu e Bourdieu (2006) sobre a fotografia como fonte para a compreensão das relações sociais do passado, cabe-nos olhar com cuidado para a questão da indumentária dos estudantes. Na imagem, observamos que há alunos vestidos de formas distintas, ao passo que a depoente sinalizou a existência de uma diferença significativa entre o que era exercido por ela - maior liberdade na vestimenta - e por seu colega Walter nesse tocante. Ao analisar a inserção de Nilza Vieira em sua comunidade disciplinar (Goodson, 1997), ao menos em sua referência a Walter Veiga da Silva, nos parece que sua flexibilização pode estar relacionada ao sentimento de pertencimento e notoriedade dentro de tal grupo, uma vez que no início da década de 1970, a professora já desfrutava de certa singularidade por ter escrito livros didáticos de Ciência e atuado no CECIGUA. Assim, não por acaso, o espetáculo oferecido àqueles que passavam, segundo Nilza, e se viam inseridos na aula de campo, apesar da informalidade que em tese estava presente nas atividades, também pode ser entendido como outra faceta da busca por reforçar tal prestígio e reconhecimento:

Sempre que a gente se aproximava dali, o povo já nos cercava e sabia o que ia acontecer. Era um ponto de honra nosso devolver a maioria dos animais ao mar. Então os bichos eram mantidos em bacias com água sempre trocada para que não morressem e na hora de ir embora eles devolvidos ao mar. Era quando o povo protestava: "Mas vai devolver por quê? Por que não leva?”.

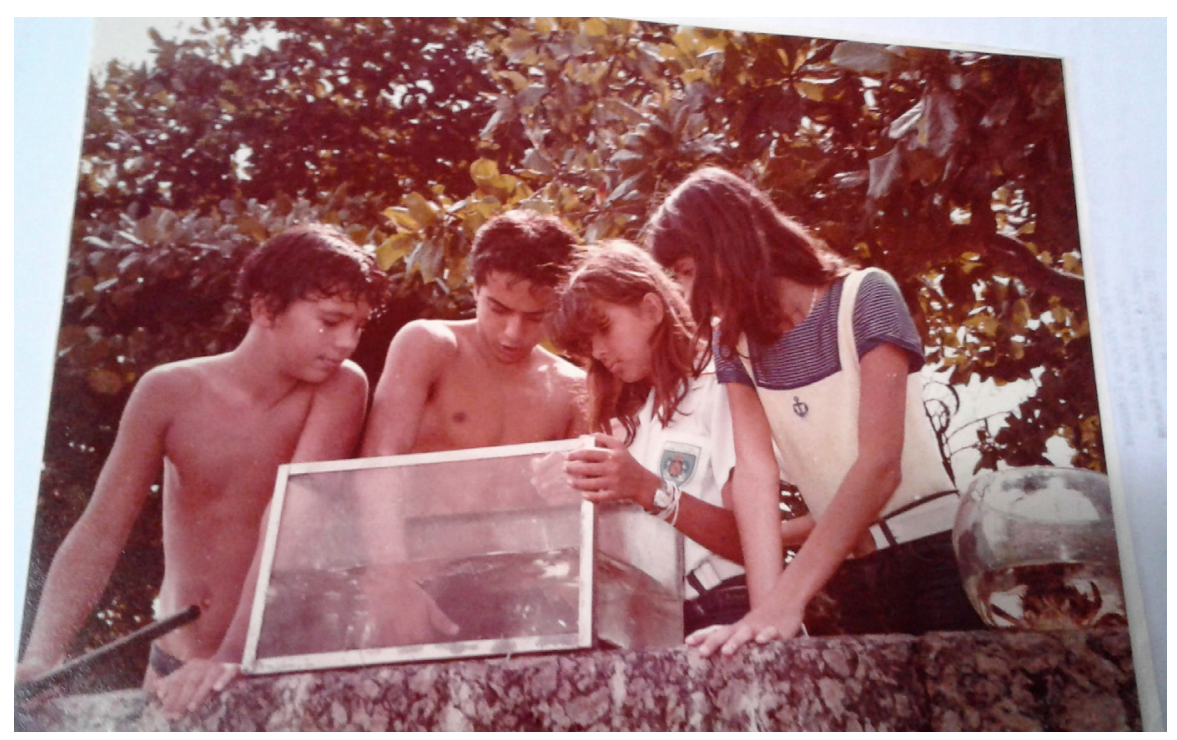

Figura 11. Alunos de Nilza Vieira em aula de campo manuseando animal marinho em um aquário

Fonte: Acervo fotográfico pessoal de Nilza Vieira. 
Além de se monumentalizar como a que não apenas ensinava o conhecimento sobre os seres marinhos, a referência ao "ponto de honra" ao devolver os animais ao mar, marca que valorizava a vida desses animais e, logicamente, o cuidado com o ambiente. Dava assim lições de ambientalismo, indicando que estava atenta e antecipava ideias de Educação Ambiental integrada à disciplina escolar Ciências, algo que se intensificou a partir da década de 1980, como indicam Fracalanza (2009) e Gomes (2008).

Por outro lado, naquele momento em que se desenrolava uma intensa massificação da escola pública e o início dos processos de precarização da profissão docente (Cunha, \& Góes, 2002), uma adaptação curiosa elaborada por Nilza Vieira e seus colegas para manter um aquário de água salgada na escola foi produzida:

Então os bichos bonitos eram todos devolvidos vivos ao mar. E uns pouquinhos, os que a gente pudesse manter vivos, iam pra sala de aula, pra escola, no nosso aquário feito de caixa d'água que é muito mais barato do que o vidro. Aí eram mantidos ali.

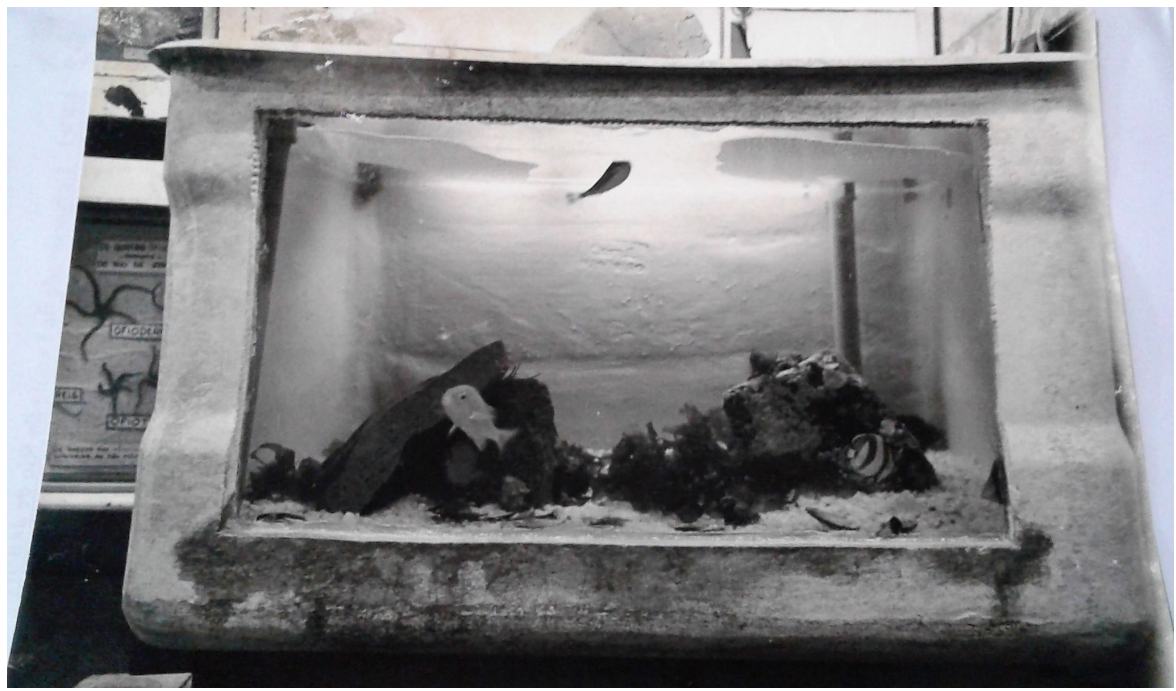

Figura 12. Exemplar de aquário produzido a partir de uma caixa d’água

Fonte: Acervo fotográfico pessoal de Nilza Vieira.

Esse improviso para a construção do aquário também entrava em sintonia com os princípios do "Movimento de Renovação", uma vez que o mesmo argumentava em prol da utilização de materiais disponíveis no dia a dia para a confecção de instrumentos e aparelhos de cunho científico e a elaboração de atividades e experimentos ${ }^{10}$. Além disso, era esperado que os currículos da disciplina escolar Ciências privilegiassem a integração entre diferentes áreas do conhecimento científico, como Física, Química, Biologia e a emergente Educação Ambiental, e fossem fundamentados por abordagens didáticas experimentais.

10 Como o Movimento de Renovação do Ensino de Ciências foi difundido e apoiado por agências financiadoras externas, foram traduzidos e passaram a circular no Brasil diversos manuais de produção de laboratórios escolares, experimentos e uso de materiais de baixo custo de outros países e da UNESCO, como sinalizam Marandino, Selles e Ferreira (2009). 
Naquele momento, permaneciam potentes as ideias da "Ciência posta em prática", do "ensino por redescoberta" e a ressignificação do "método de projetos", ao lado da defesa da Ciência Integrada para o Ensino Fundamental e os cursos de Licenciatura Curta (Ayres, Lima-Tavares, Ferreira, \& Selles, 2012). Tais proposições enfatizavam o processo de investigação científica em sala de aula, a valorização das atividades práticas e a reorganização de conteúdos para uma integração curricular ainda maior das áreas do conhecimento científico para que os estudantes desenvolvessem atitudes mais "científicas" quando se deparassem com problemas cotidianos (Barra, \& Lorenz, 1986; Fracalanza, 2009). Constituída pelos discursos que apontavam tais abordagens como soluções para as dificuldades educacionais, também cabia à disciplina escolar Ciências desenvolver um "espírito crítico" no corpo estudantil (Fracalanza, 2009). O conhecimento, portanto, não seria contemplativo, mas se colocaria de forma prática a serviço de questionamentos que envolvessem identificação e investigação de problemas, elaboração e teste de hipóteses, análise de dados e verificações experimentais (Lorenz, 2004).

Interessantemente, Nilza Vieira enfatiza o impacto que, ao seu ver, ocorreu na formação dos alunos educados de acordo com esses preceitos e que depois prosseguiram estudos universitários nas Ciências Biológicas para explicar por que muitos desejavam auxiliá-la nas aulas em campo, quando estagiavam no curso de Licenciatura:

E nessa de criança ensina criança, nesse movimento de um ensinar o outro, a gente incentivava que os alunos da universidade, abaixados, ensinassem a crianças bem menores, bem pequenas. Por que ele [estagiário] também tinha sido uma criança professora no tempo dele. Ele também aprendeu e aqui estava resgatando essa história, estava devolvendo à escola o conhecimento que ele foi acumulando por ser mais velho.

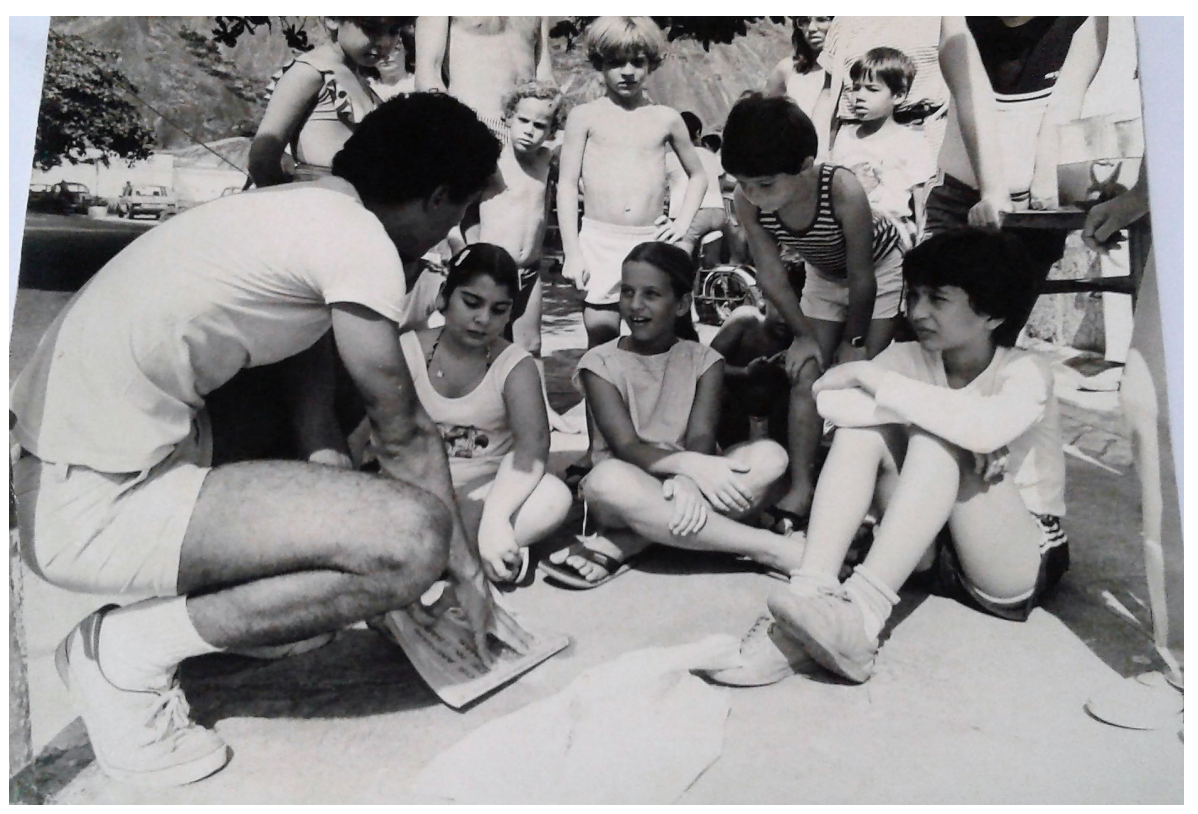

Figura 13. Estagiário conversa com alunos em aula de campo na Praia da Urca

Fonte: Acervo fotográfico pessoal de Nilza Vieira. 
Por fim, a fotobiografia de nossa depoente foi finalizada com o retorno à foto em que está o Doutor Moisés (Figura 1), e que deu início à narrativa, para denotar que ela encontrou sentido em sua prática profissional ao estabelecer similaridades entre seu perfil e o do professor que ela tanto reverenciava. Nilza parece assim querer explicitar sua crença de que as tradições de ensino são aprendidas com bons exemplares. Igualmente, que o método que utilizava e sua confiança num modo de ensino horizontalizado são capazes de inserir os alunos da escola pública em funções sociais mais valorizadas que a própria docência. Ou pelo menos reafirmar, ao mesmo tempo, que atribuía fama aos docentes que, segundo seu juízo, se destacavam:

E nesse ir e vir formamos gente para o mundo. Aqui um orgulho: o José Carlos, meu aluno de $5^{\text {a }}$ série, virou um cirurgião cardíaco famoso. Assim como o Doutor Moisés, que foi o início da minha história, foi um professor famoso aos meus olhos.

Ao zelar e fazer parte dessas fotografias, Nilza Vieira parece ter querido assegurar de que haveria um testemunho material de suas práticas pedagógicas. Testemunho esse capaz também de advogar em prol de sua dignidade e probidade enquanto docente em caso de questionamentos. Assim, nos deparamos com uma forma de conhecer e analisar a singularidade das práticas e visões de mundo contemplados na fala de Nilza Vieira. O caráter processual da atividade biográfica, com suas hesitações, omissões e hipérboles nos indica pistas de como nossa entrevistada deu forma e sentido às experiências e aos acontecimentos que atravessaram sua trajetória diante da realidade social, enquanto a mesma se constituía enquanto professora de Ciências (Delory-Momberger, 2012).

\section{Considerações finais}

No presente texto, apresentamos a fotobiografia como um dispositivo metodológico que inspirou esta pesquisa, partindo de reflexões do campo sociológico que versam sobre abordagens compreensivas e buscando estabelecer pontes entre estas e referenciais consolidados da História da Educação e do Currículo. Realizamos um exercício que, acreditamos, têm potencial para enriquecer a produção da história da disciplina escolar Ciências.

Assim, diante da demanda por novas pesquisas que relacionem às trajetórias de docentes dessa disciplina com as transformações curriculares operadas sobre a mesma, o uso do dispositivo fotobiográfico pode permitir que se conheça e se compreenda atravessamentos entre histórias de vida, formação profissional, atuação docente e concepções didáticas. Focalizamos, ainda nesse escopo, a trajetória da professora de Ciências Nilza Vieira, reconhecida como uma docente carioca que se engajou ao "Movimento de Renovação do Ensino de Ciências" desenvolvido no Brasil a partir de meados do século passado. Com o acionamento do dispositivo fotobiográfico, pudemos entrar em contato com algumas de suas concepções educativas e práticas pedagógicas, provavelmente, as mais expressivas.

Em nosso estudo, aproximamo-nos desses aspectos ao analisarmos atividades desenvolvidas pela docente em campo, na Praia da Urca no Rio de Janeiro, que 
contemplavam aulas abertas ao público, nas quais estudantes e estagiários atuavam coletando, manuseando, observando e estudando a biologia de seres vivos marinhos. Investigando os retratos e problematizando sua narrativa, elencamos algumas considerações e suscitamos reflexões ao longo da fotobiografia sobre a formação, a trajetória, a atuação e a experiência profissional da professora.

Destarte, a partir da construção e da mobilização do dispositivo fotobiográfico, é possível para o entrevistado cruzar simultaneamente a fonte oral com a fonte imagética na produção de uma narrativa mais densa em sentidos que podem ser explorados na pesquisa com a história do currículo da disciplina escolar Ciências. Contudo, se o aporte fotobiográfico carrega em si novas oportunidades para produção de narrativas sobre o passado, algumas ressalvas também precisam ser feitas sobre seus limites e desafios.

O primeiro deles é que, diante da cultura do esquecimento (Nunes, 2004) cultivada na sociedade brasileira, pode ser difícil encontrar fotografias que registram práticas pedagógicas e construções curriculares realizadas no passado. Se hoje, fotografar é uma atividade ordinária, não podemos ignorar que até o final dos anos 2000, os registros não eram realizados de modo abundante por diversos motivos.

O segundo é que o trabalho com o dispositivo fotobiográfico exige que exista um narrador que possa contar com coerência uma história sobre as fotografias. Às vezes, as fotografias podem estar disponíveis, mas não haver alguém para narrá-las. Isso significa, que, assim como todo o trabalho de História Oral, é necessário que existam sujeitos que possam ser entrevistados e estejam lúcidos. Quanto mais distante do presente for o recorte temporal da pesquisa, maior será a dificuldade para encontrá-los até que se chegue à impossibilidade de se localizar pessoas vivas para atuarem como depoentes.

Também é indispensável ressaltar que as memórias são construções subjetivas sobre o passado, atualizadas e renovadas no tempo presente, capazes de reconstituir representações e interpretações (Delgado, 2011). É preciso, portanto, que estejamos conscientes das limitações e imperfeições de operar com elas: não há imparcialidade ou neutralidade e é necessário evidenciar conflitos e dissensos nas construções narrativas (Joutard, 2000; Portelli, 1997). Assim, somar as fotobiografias à pesquisa documental e ao cruzamento com outras fontes é importante para a consolidação de um sólido arcabouço que colabore para a matização de certezas sobre a história da disciplina escolar Ciências.

Acreditamos também ser pertinente uma última reflexão metodológica sobre a fotobiografia: quem a detém? O pesquisador ou o biografado? As fotos selecionadas como fonte para o dispositivo fotobiográfico não são por si só a fotobiografia. Quem a produz é o pesquisador, em última instância, em interação entre a seleção que o biografado faz e a narrativa construída de forma dialógica na entrevista. À seleção caberia perguntar: por que estas fotografias e não outras? O que parece ter movido o biografado a tirá-las de determinado modo? Com que fins foram feitas? Foram utilizadas em outros momentos? Assim, a fotobiografia vai ao encontro das reflexões trazidas sobre a memória (Le Goff, 1996; Nora, 1993; Pollak, 1989, 1992): ela está sendo narrada no presente, submetida às condições de produção dos dados. Portanto, não é espontânea ou dada a priori. Outro 
ponto a ser mencionado é que diversos outros aspectos sociais, culturais, pedagógicos e históricos poderiam ser abordados a partir do exame do material fotográfico. A partir do momento em que assumimos as fotografias e outras imagens como fontes históricas, uma gama de perguntas e reflexões podem ser elaboradas com base nestes registros. Assim, múltiplas análises e debates são passíveis de construção a partir dos interesses e recortes de pesquisa e das questões de análise formuladas (Burke, 2004).

Por fim, a despeito das ponderações acima, resta-nos uma última reflexão: diante do cenário sócio-histórico atualmente vivido no Brasil e no mundo de acirramento do totalitarismo e do revisionismo histórico complacente com regimes autoritários, é possível ou desejável ignorar tais procedimentos investigativos que nos permitem amalgamar as experiências e os sentimentos dos sujeitos - pessoas comuns, mas também integrantes dos movimentos históricos - na escrita de nossas versões para a história do currículo de Ciências?

\section{Referências}

Abrantes, A. C. S., \& Azevedo, N. (2010). O Instituto Brasileiro de Educação, Ciência e Cultura e a institucionalização da ciência no Brasil, 1946-1966. Boletim do Museu Paraense Emílio Goeldi. Ciências Humanas, 5(2), 469-492.

Ayres, A. C. M., \& Selles, S. E. (2012). História da formação de professores: diálogos com a disciplina escolar ciências no ensino fundamental. Ensaio: Pesquisa em Educação em Ciências, 14, 95-107.

Ayres, A. C. M., Lima-Tavares, D., Ferreira, M. S., \& Selles, S. L. (2012). Licenciaturas de curta duração (1965 e 1974) e disciplina escolar ciências: aproximações sócio-históricas. In S. E. Selles, \& M. Cassab. (Orgs.). Currículo, docência e cultura (pp. 53-74). Editora da UFF.

Azevedo, M. (2020). Entre a bancada e a sala de aula - A experimentação no período de ouro do Ensino de Ciências. Appris Editora.

Azevedo, M., Selles, S. E., \& Lima-Tavares, D. (2016). Relações entre os movimentos reformistas educacionais do ensino de ciências nos Estados Unidos e Brasil na década de 1960. Educação em Foco, 21, 237-257. https://doi.org/10.22195/2447-524620162119665

Barra, V. M., \& Lorenz, K. M. (1986). Produção de materiais didáticos de ciência no Brasil, período: 1950 a 1980. Ciência e Cultura, 38(12), 1970-1983.

Berteaux, D. (2009). Metodologia do Relato de Vida em Sociologia. In N. M. Takeuti, \& C. Niewiadomski (Orgs.). Reinvenções do sujeito social: teorias e práticas biográficas (pp. 23-32). Sulina.

Bertaux, D. (2014). A vingança do curso de ação contra a ilusão cientificista. Civitas, $14(2), 250-271$. 
Bourdieu, P. (1996). A ilusão biográfica. In J. Amado, \& M. M. Ferreira (Orgs.). Usos e Abusos da História Oral (pp. 183-191). Editora da Fundação Getúlio Vargas.

Bourdieu, P., \& Bourdieu, M. C. (2006). O camponês e a fotografia. Rev. Sociol. Polit, 26, 31-39.

Bruno, F. (2014). Fotobiografia: uma proposta antropológica e estética. Revista Espaço Acadêmico, 163, 9-20.

Burke, P. (2014). O Testemunho das Imagens. In: P. Burke. Testemunha Ocular: história e imagem (pp. 11-24). EDUSC.

Cassab, M. (2010). A produção em História das Disciplinas Escolares pela escrita de pesquisadores brasileiros. Revista Brasileira de História da Educação, 23, 225-251.

Cassab, M. (2015). O movimento renovador do ensino das ciências: entre renovar a escola secundária e assegura o prestígio social da ciência. Revista Tempos e Espaços em Educação, 8, 19-35. https://doi.org/10.20952/revtee.v0i0.3938

Chervel, A. (1990). História das disciplinas escolares: reflexões sobre um campo de pesquisa. Teoria \& Educação, 2, 177-229.

Cunha, L. A., \& Góes, M. (2002). O golpe na educação. 11. ed. Jorge Zahar.

Delgado, L. A. N. (2011). História Oral: memória, tempo, identidades. 2. ed. Autêntica.

Delory-Momberger, C. (2012). Abordagens metodológicas na pesquisa biográfica. Revista Brasileira de Educação, 17(51), 523-536.

Dubar, C. (1998). Trajetórias sociais e formas identitárias: alguns esclarecimentos conceituais e metodológicos. Educação \& Sociedade, 19(62), 13-30.

Fonseca, M. V. R., Xavier, M. T., Vilela, C. L., \& Ferreira, M. S. (2013). Panorama da produção brasileira em história do currículo e das disciplinas acadêmicas e escolares (2000-2010): entre a História da Educação e a Sociologia do Currículo. Revista Brasileira de História da Educação, 13, 193-225.

Forquin, J. C. (1992). Saberes escolares, imperativos didáticos e dinâmicas sociais. Teoria \& Educação, 1(5), 28-49.

Fracalanza, H. (2009). Histórias do ensino de Biologia no Brasil. In S. E. Selles, M. S. Ferreira, M. A. Barzano, \& E. P. Q. Silva (Orgs). Ensino de Biologia: histórias, saberes e práticas formativas (pp. 25-48). EdUFU.

Fracalanza, H., Amaral, I. A., \& Gouveia, M. S. F. (1987). O ensino de ciências no primeiro grau. Atual, $124 \mathrm{p}$.

Gomes, M. M. (2006) Conhecimentos ecológicos em livros didáticos de ciências: aspectos sócio-históricos de sua constituição. (Tese de Doutorado em Educação). Programa de Pós-Graduação em Educação da Universidade Federal Fluminense, Niterói. 
Gomes, M. M., Selles, S. E., Lopes, A. C. (2013). Currículo de Ciências: estabilidade e mudança em livros didáticos. Educação e Pesquisa (USP. Impresso), 39, 477-492. https:// doi.org/10.1590/S1517-97022013000200013

Goodson, I. F. (1992). Dar voz ao professor: as histórias de vida dos professores e seus desenvolvimentos profissionais. In A. Nóvoa (Org.). Vidas de professores (pp. 63-78). Porto.

Goodson, I. F. (1997). A Construção Social do Currículo. Educa.

Goodson, I. F. (2007). Questionando as reformas educativas: a contribuição dos estudos biográficos a educação. Pro-posições, 18, (2), 17-37.

Goodson I. F. (2015) Narrativas em educação: a vida e a voz dos professores. Porto Editora.

Joutard, P. (2000). Desafios à História oral do século XXI. In M. M. Ferreira, T. Fernandes, \& V. Alberti. (Orgs). História Oral: desafios para o século XXI (pp. 31-46). Fundação Getúlio Vargas.

Krasilchik, M. (2000). Reformas e realidade: o caso do ensino das ciências. São Paulo em Perspectiva, 14(1), 85-93.

Le Goff, J. (1996). Memória e História. Editora da UNICAMP.

Lelis, I. A. O. M. (2014). A construção social da profissão docente no Brasil: uma rede de histórias. In M. Tardif, \& C. Lessard (Orgs.). O ofício de professor: história, perspectivas e desafios internacionais (pp. 54-66). 6 ed. Vozes.

Lelis, I. A. O. M, \& Nascimento, M. G. C. A. (2010). Trajetórias de professores: a pesquisa com histórias de vida. In A. W. P. Mendonça (Org.). História e Educação: dialogando com as fontes (pp. 253-272). 1 ed. Forma e Ação.

Levi, G. Usos da biografia (1996). In J. Amado, \& M. M. Ferreira (Orgs.). Usos e Abusos da História Oral (pp. 167-182). Rio de Janeiro: Editora da Fundação Getúlio Vargas.

Lopes, S. M. C. N. (2013). Professores inesquecíveis: docência e prestígio no Instituto de Educação do Rio de janeiro dos anos 1950-60. In Anais do VII Congresso Brasileiro de História da Educação. Cuiabá, MT.

Lopes, S. M. C. N. (2016). Os notáveis do Instituto de Educação: professores catedráticos do curso normal nos anos 1950-60. Educação em Foco (Juiz de Fora), 21, 157-183. https://doi.org/10.22195/2447-524620162119727

Lorenz, K. M. (2004) As Reformas do Ensino das Ciências no Ensino Secundário Brasileiro nas Décadas de 1960 e 1970. Revista Portuguesa de Pedagogia, 39(1), 97-112.

Loriga, S. (1998). A biografia como problema. In J. Revel (Org.). Jogos de escalas: a experiência da microanálise. Editora da Fundação Getúlio Vargas. 
Lozano, J. E. A. (1996). Prática e Estilos de Pesquisa Histórica Oral Contemporânea. In J. Amado, \& M. M. Ferreira (Orgs). Usos e Abusos da História Oral. Rio de Janeiro: Fundação Getúlio Vargas.

Marandino, M., Selles, S. E., \& Ferreira, M. S. (2010). Ensino de Biologia: histórias e práticas em diferentes espaços educativos. Cortez.

Nora, P. (1993). Entre memória e história: a problemática dos lugares. Projeto História. São Paulo, 10, 07-28.

Nunes, C. (2004). Memória e História da Educação: entre práticas e representações. Educação em Foco - História da Educação, 07(12), 01-17.

Pollak, M. (1989). Memória, esquecimento, silêncio. Estudos Históricos, 2(3), 3-15.

Pollak, M. (1992). Memória e identidade social. Estudos Históricos, 15(10), 200-212.

Portelli, A. (1997). O que faz a História Oral diferente. Projeto História, 14, 25-39.

Santos, M. C. F., \& Selles, S. E. (2014). A produção da disciplina escolar história natural na década de 1930: os livros didáticos de Waldemiro Potsch para o ensino secundário. Cadernos de Pesquisa em Educação, 19, 45-68. https://doi.org/10.22535/cpe.vli39.10729

Scarton, J. G. E., \& Selles, S. E. (2012). Narrativas docentes de práticas em educação ambiental na Escola Municipal Camilo Castelo Branco. In Anais do VI Encontro Regional de Ensino de Biologia do Rio de Janeiro e Espírito Santo. Rio de Janeiro, RJ.

Vieira, C. O. F., Vieira, N. B. P., \& Silva, W. M. V. (1970). Cadernos MEC: Iniciação à ciência. MEC/FENAME.

Vieira, C. O. F., Vieira, N. B. P., \& Silva, W. M. V. (1972) Iniciação à ciência: guia metodológico para cadernos MEC. MEC/FENAME. 
Rodrigo Cerqueira do Nascimento Borba

${ }^{\infty}$ https://orcid.org/0000-0002-4504-5793 Universidade Federal Fluminense Grupo de Pesquisa Currículo, Docência e Cultura (CDC/UFF/CNPq) Niterói, Rio de Janeiro, Brasil rodrigocnb@gmail.com

Sandra Escovedo Selles

https://orcid.org/0000-0002-7921-0478 Universidade Federal Fluminense (UFF)

Faculdade de Educação Niterói, Rio de Janeiro, Brasil escovedoselles@gmail.com

Submetido em 10 de abril de 2020 Aceito em 03 de junho de 2020 Publicado em 29 junho de 2020 